\title{
Grain yield and quality of common bean cultivars in response to nitrogen
}

\section{Produtividade e qualidade de grãos de cultivares de feijão comum em resposta ao nitrogênio}

\author{
Bruno Corrêa AIRES'; Rogério Peres SORATTO²; Fernando Vieira Costa GUIDORIZZI' \\ ${ }^{1}$ Mestre em Agronomia-Agricultura, Universidade Estadual Paulista, Faculdade de Ciências Agronômicas, Botucatu, SP, \\ Brasil. \\ 2 Professor Associado, Universidade Estadual Paulista, Faculdade de Ciências Agronômicas, Departamento de Produção \\ e Melhoramento Vegetal, Av. Universitária, 3780, 18610-034, Botucatu, SP, Brasil. Autor para correspondência: \\ rogerio.soratto@unesp.br
}

Recebido em: 18-10-2018; Aceito em: 18-01-2019

\begin{abstract}
Nitrogen $(\mathrm{N})$ is the nutrient most required by common bean, and the response to $\mathrm{N}$ fertilization may be variable among genotypes. The objective of this work was to evaluate the $\mathrm{N}$ nutrition, grain yield, grain size, and crude protein concentration of common bean cultivars in response to topdressing $\mathrm{N}$ rates. Two experiments were conducted on a Typic Rodudalf, under two growth conditions ("dry" and "rainy" seasons). A randomized complete block design with a $7 \times 4$ factorial arrangement and four replicates was used. The treatments consisted of seven cultivars (Pérola, BRS Ametista, BRS Notável, IPR Campos Gerais, IPR Tangará, IAC Formoso, and IAC Imperador) and four $\mathrm{N}$ rates $\left(0,35,70\right.$, and $\left.140 \mathrm{~kg} \mathrm{ha}^{-1}\right)$. The experiments were analyzed jointly. The application of $\mathrm{N}$ did not affect the cycle, plant population, and number of grains per pod, but increased the leaf $\mathrm{N}$ concentration, number of pods per plant, grain size, and grain yield, regardless of the cultivar. The responses of common bean cultivars to $\mathrm{N}$ rates varied according to the growth condition, with response to $\mathrm{N}$ only in the "rainy" season experiment, under conditions of lower $\mathrm{N}$ and higher $\mathrm{C} / \mathrm{N}$ ratio in the straw of the preceding crop. The crude protein concentration in the grains was influenced in an inconsistent manner by the factors studied.
\end{abstract}

Additional keywords: genotype; grain size; nitrogen fertilization; Phaseolus vulgaris; protein.

\section{Resumo}

$\mathrm{O}$ nitrogênio $(\mathrm{N})$ é o nutriente mais exigido pelo feijoeiro comum, e a resposta à adubação nitrogenada pode ser variável entre os genótipos. O objetivo deste trabalho foi avaliar a nutrição nitrogenada, a produtividade de grãos, o tamanho dos grãos e o teor de proteína bruta nos grãos de cultivares de feijão comum em resposta a doses de $\mathrm{N}$ em cobertura. Foram conduzidos dois experimentos em um Nitossolo Vermelho, porém sob duas condições de cultivo (safras "da seca" e "das águas"). Adotou-se o delineamento em blocos casualizados, com fatorial $7 \times 4 \mathrm{e}$ quatro repetições. Os tratamentos foram constituídos por sete cultivares (Pérola, BRS Ametista, BRS Notável, IPR Campos Gerais, IPR Tangará, IAC Formoso e IAC Imperador) e quatro doses de N (0, 35, 70 e $\left.140 \mathrm{~kg} \mathrm{ha}^{-1}\right)$. Procedeu-se à análise conjunta dos experimentos. A aplicação de $\mathrm{N}$ não afetou o ciclo, a população de plantas $\mathrm{e}$ o número de grãos por vagem, mas incrementou o teor de $\mathrm{N}$ na folha, o número de vagens por planta, o tamanho dos grãos e a produtividade de grãos, independentemente da cultivar. As respostas das cultivares do feijoeiro comum às doses de $\mathrm{N}$ variaram em função da condição de cultivo, com resposta ao $\mathrm{N}$ apenas no experimento "das águas", sob condições de menor quantidade de $\mathrm{N}$ e maior relação $\mathrm{C} / \mathrm{N}$ na palhada da cultura precedente. O teor de proteína bruta nos grãos foi influenciado de maneira pouco consistente pelos fatores estudados.

Palavras-chave adicionais: adubação nitrogenada; genótipo; Phaseolus vulgaris; proteína; tamanho do grão.

\section{Introduction}

The total bean cultivation area in Brazil is approximately 3.2 million ha, with a production of 3.4 million tons of grains, where common bean (Phaseolus vulgaris L.) is the main cultivated species (CONAB, 2018). In the last decades, Brazilian breeding programs in common bean have given greater emphasis on obtaining cultivars with carioca-type grains (Lemos et al., 2015). Currently, $65-70 \%$ of the total common bean produced and consumed in Brazil has cariocatype grains (Lemos et al., 2015; CONAB, 2018). Cultivar Pérola, with carioca-type grain, stood out as one of the most cultivated cultivars until very recently, having a significant planted area in some regions; however, several other cultivars have been constantly released to the market (Lemos et al., 2015).

Nitrogen $(\mathrm{N})$ is the nutrient most extracted by 
the common bean plant and removed by its grains (Soratto et al., 2013b). It is a constituent of many components of plant cells, such as amino acids, proteins, and nucleic acids, giving the plants greater vegetative development and, consequently, greater photoassimilate production and yield (Malavolta et al., 1997; Soratto et al., 2004; Maia et al., 2017). However, the N cycle in the soil-plant system is complex, and factors such as climatic conditions, soil type and management, preceding crops, among others, affect the response of crops to N fertilization (Cantarella, 2007; Soratto et al., 2013a; Soratto et al., 2014, Maia et al., 2017). Thus, adequate $\mathrm{N}$ management is considered one of the main practices to obtain high yields in common bean crop, especially when cultivated in areas with high technology use (Santos \& Fageria, 2007; Soratto et al., 2004; Soratto et al., 2013a, Soratto et al., 2014; Amaral et al., 2016; Maia et al., 2017).

Nitrogen fertilization recommendations for common bean vary according to the area history and the expected grain yield considering the technological level, with rates varying from 40 to $110 \mathrm{~kg} \mathrm{ha}^{-1} \mathrm{~N}$ (Ambrosano et al., 1997; Chagas et al., 1999; Sousa \& Lobato, 2004). However, according to Santos \& Fageria (2007) and Salgado et al. (2012), common bean cultivars differ in response to $\mathrm{N}$ management. Fornasieri Filho et al. (2007) observed that cultivar Pérola showed higher grain yield in response to $\mathrm{N}$ fertilization and higher $\mathrm{N}$-use efficiency than cultivar
IAC Una; however, both cultivars showed increased grain yield up to the highest rate studied $\left(150 \mathrm{~kg} \mathrm{ha}^{-1}\right)$ in the first year, and up to the $100 \mathrm{~kg} \mathrm{ha}^{-1}$ rate in the second year. Guimarães et al. (2017) verified that cultivar Jalo Precoce presented higher grain yield with the rate of $40 \mathrm{~kg} \mathrm{ha}^{-1}$ of topdressing $\mathrm{N}$ fertilization, while for cultivar BRS Estilo, the highest grain yield was obtained with $80 \mathrm{~kg} \mathrm{ha}^{-1}$ of topdressing $\mathrm{N}$ fertilization. On the other hand, Soratto et al. (2017) obtained a linear increase in grain yield for cultivars IPR 139 and Pérola up to the rate of $180 \mathrm{~kg} \mathrm{ha}^{-1} \mathrm{~N}$. Hence, it was considered the hypothesis that there is a difference between currently used common bean cultivars for grain yield and quality in response to topdressing $\mathrm{N}$ fertilization.

The objective of this work was to evaluate the $\mathrm{N}$ nutrition, grain yield, grain size, and crude protein concentration of common bean cultivars in response to topdressing $\mathrm{N}$ rates.

\section{Materials and methods}

Two experiments (two growth conditions) were carried out in the municipality of Botucatu, São Paulo

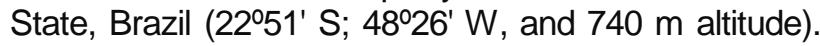
According to the Köppen classification, the predominant climate in the region is type Cwa. The climatic data recorded during the experimental periods are presented in Figure 1.

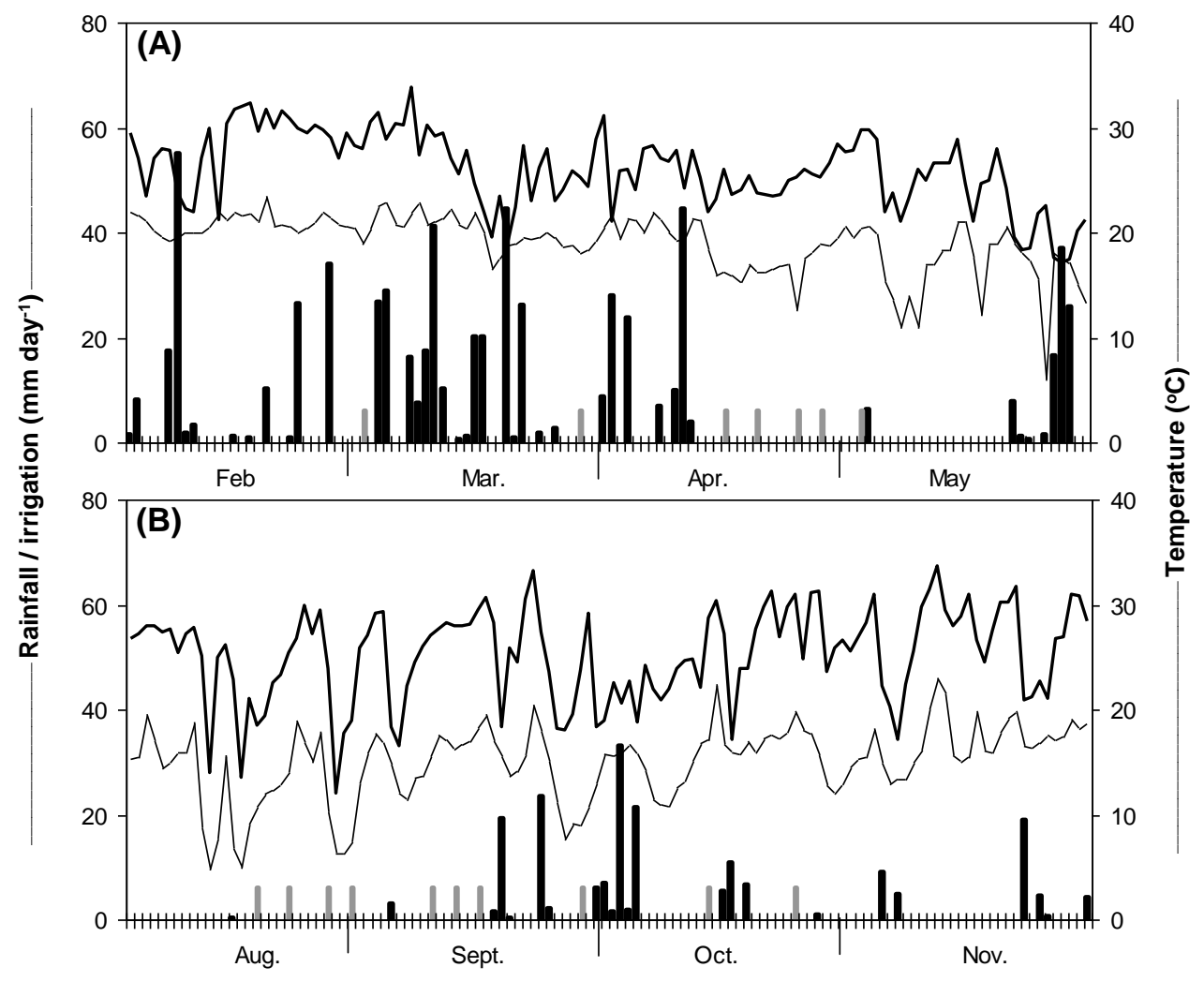

Figure 1 - Daily rainfall ( $)$, irrigation ( 1 ), maximum temperature (_), and minimum temperature (_) recorded at the experimental area from during the periods (A) from February to May ("dry" season experiment) and (B) from August to November ("rainy" season experiment), in 2013. Botucatu-SP. 
Experiments 1 and 2 corresponded, respectively, to the "dry" (February-May) and "rainy" (AugustNovember) seasons; preceding crops were black oat/millet and maize, respectively. The soil of the areas used for the experiments was classified as a Nitossolo Vermelho distroférrico, i.e., a Typic Rodudalf, with $643 \mathrm{~g} \mathrm{~kg}^{-1}$ clay, $112 \mathrm{~g} \mathrm{~kg}^{-1}$ silt, and $245 \mathrm{~g} \mathrm{~kg}^{-1}$ sand. Before common bean was sown, soil samples were collected from the 0.0-0.20-m layer. In the area used in the "dry" season, the soil had the following characteristics: $30 \mathrm{~g} \mathrm{dm}^{-3}$ organic matter; $\mathrm{pH}\left(\mathrm{CaCl}_{2}\right)$ 5.8; $61 \mathrm{mg} \mathrm{dm}^{-3} P_{\text {resin }} ; 5.1,54,27$, and $27 \mathrm{mmol}_{\mathrm{c}} \mathrm{dm}^{-3}$ $\mathrm{K}, \mathrm{Ca}, \mathrm{Mg}$, and $\mathrm{H}+\mathrm{Al}$, respectively; base saturation (BS) of $76 \%$. In the "rainy" season, the soil characteristics were as follows: $25 \mathrm{~g} \mathrm{dm}^{-3}$ organic matter; $\mathrm{pH}\left(\mathrm{CaCl}_{2}\right)$ 4.8; $38 \mathrm{mg} \mathrm{dm}^{-3} \mathrm{P}_{\text {resin; }}$ 6.2, 36, 11, and $45 \mathrm{mmolc}_{\mathrm{cm}} \mathrm{dm}^{-3} \mathrm{~K}, \mathrm{Ca}, \mathrm{Mg}$, and $\mathrm{H}+\mathrm{Al}$, respectively; BS of $46 \%$. The desiccation of plants present in the experimental areas was performed 15 days before sowing, using herbicide glyphosate at the rate of $2,160 \mathrm{~g}$ a.i. ha ${ }^{-1}$. Ten days after desiccation, crop residues were managed with the use of a straw mower. Samples of the straw remaining on the soil were collected one day before sowing for both experiments, using a $0.25-\mathrm{m}^{2}$ area frame. These samples were dried at $65^{\circ} \mathrm{C}$ for $72 \mathrm{~h}$, being subsequently weighed. We observed the equivalent of $3,882 \mathrm{~kg} \mathrm{ha}^{-1}$ dry matter (DM) for the "dry" season, and 4,253 kg ha-1 DM for the "rainy" season. The dried material was ground and subjected to analysis of $\mathrm{N}$ and $\mathrm{C}$ concentrations (Malavolta et al., 1997). The amount of $\mathrm{N}$ in the remaining straw was obtained by multiplying the DM amount present at the soil surface by the $\mathrm{N}$ concentration at that straw. The $\mathrm{C} / \mathrm{N}$ ratio was obtained by dividing the concentrations of these elements in the straw. Values of 61 and $46 \mathrm{~kg} \mathrm{ha}^{-1} \mathrm{~N}$ were observed for the "dry" and "rainy" season experiments, respectively, with $\mathrm{C} / \mathrm{N}$ ratios of 26 and 31 .

In both experiments, the experimental design was randomized blocks in a $7 \times 4$ factorial scheme with four replicates. The treatments consisted of seven common bean cultivars of the commercial group Carioca (Pérola, BRS Ametista, BRS Notável, IPR Campos Gerais, IPR Tangará, IAC Formoso, and IAC Imperador) and four topdressing $N$ rates $(0,35,70$, and $\left.140 \mathrm{~kg} \mathrm{ha}^{-1}\right)$. Each experimental unit consisted of four $6-\mathrm{m}$ long rows, with spacing of $0.45 \mathrm{~m}$ between rows. The two central rows were considered for evaluations, excluding $0.5 \mathrm{~m}$ from the ends of each evaluation row.

The common bean sowing was performed mechanically with a seeder-fertilizer machine, model SPH 249, on 02/20/2013 in the "dry" season and on 08/15/2013 in the "rainy" season, distributing 16 seeds per meter of furrow. Seeds were treated with fungicide carboxin + thiram $\left(60+60 \mathrm{~g}\right.$ a.i. $\left.100 \mathrm{~kg} \mathrm{seed}^{-1}\right)$, insecticide thiamethoxan $\left(100 \mathrm{~g}\right.$ a.i. $\left.100 \mathrm{~kg} \mathrm{seed}^{-1}\right)$, and cobalt + molybdenum $(4.5+45 \mathrm{~g}$ per $100 \mathrm{~kg}$ seeds $)$. In both experiments, $150 \mathrm{~kg} \mathrm{ha}^{-1}$ of the formulated ferti- lizer 08-28-16 of $\mathrm{N}-\mathrm{P}_{2} \mathrm{O}_{5}-\mathrm{K}_{2} \mathrm{O}$ was applied in sowing fertilization. Emergences occurred at 6 and 11 days after sowing in the "dry" and "rainy" seasons, respectively. Topdressing $N$ fertilization (ammonium nitrate) was performed in the $\mathrm{V}_{4}$ stage. Thus, in the "dry" season, $N$ fertilization was carried out on 03/13/2013 (16 days after emergence - DAE) for cultivars IAC Imperador and BRS Notável, and on 03/18/2013 (21 DAE) for the other cultivars. In the "rainy" season, in turn, N fertilization was carried out on 09/12/2013 (17 DAE) for cultivars IAC Imperador and BRS Notável, and on 09/18/2013 (23 DAE) for the other cultivars.

Phytosanitary treatments were carried out throughout the development cycle of common bean using herbicides fluazifop-p-butyl + fomesafen (125 + $+250 \mathrm{~g}$ a.i. ha $^{-1}$ ), insecticides thiamethoxam + lambdacyhalothrin $\left(35.3+26.5 \mathrm{~g}\right.$ a.i. ha $\left.{ }^{-1}\right)$, acephate (450 g a.i. ha $\left.{ }^{-1}\right)$, flubendiamide (34 g a.i. ha $\left.{ }^{-1}\right)$, and methomyl (108 g a.i. ha-1), and fungicides azoxystrobin (50 g a.i. ha $\left.{ }^{-1}\right)$, fluzinam (750 g a.i. ha $\left.{ }^{-1}\right)$, fentin hydroxide (280 $\mathrm{g}$ a.i. ha-1 ${ }^{-1}$, procymidone (750 $\mathrm{g}$ a.i. ha $\left.{ }^{-1}\right)$, and thiophanate-methyl + chlorothalonil $(400+$ $+1000 \mathrm{~g}$ a.i. ha $^{-1}$ ). Water (supplementary irrigation) was supplied by a conventional sprinkler irrigation system, with a $6 \mathrm{~mm}$ depth applied in each irrigation, according to the crop need.

At the $R_{6}$ stage of each cultivar, 30 leaves (third fully-expanded leaf from the apex) were collected per plot (Ambrosano et al., 1997). The leaves were washed in distilled water and dried at $65^{\circ} \mathrm{C}$ for $72 \mathrm{~h}$. Subsequently, these leaves were ground and subjected to $\mathrm{N}$ concentration analysis (Malavolta et al., 1997). The cycle was determined as the number of days elapsed from sowing until the physiological maturity of $90 \%$ of the plants of the plot. At the time of physiological maturity, production components (number of pods per plant, number of grains per pod, and 100-grain weight) were evaluated in ten plants per plot. Plant population and grain yield $\left(\mathrm{kg} \mathrm{ha}^{-1}\right)$ were evaluated in two 3-m long rows per plot. The data of 100 -grain weight and grain yield were corrected to $13 \%$ water (wet basis).

The grains harvested in each plot were classified through sieves with oblong holes numbers 10 $(3.97 \times 19.05 \mathrm{~mm}), 11(4.37 \times 19.05 \mathrm{~mm}), 12(4.76 \times$ $\times 19.05 \mathrm{~mm}), 13(5.16 \times 19.05 \mathrm{~mm}), 14(5.56 \times$ $\times 19.05 \mathrm{~mm})$, and $15(5.95 \times 19.05 \mathrm{~mm})$. With the results, relative sieved grain yield (RSGY) and sieve yield (SY) were calculated according to Carbonell et al. (2010). Grain samples were oven dried at $65 \stackrel{\circ}{ } \mathrm{C}$ for $72 \mathrm{~h}$, being then ground and subjected to $\mathrm{N}$ concentration analysis (Malavolta et al., 1997). The protein concentration in the grains was determined by multiplying the $\mathrm{N}$ concentration by the index 6.25 .

The data obtained in the two experiments (growth conditions) were subjected to analysis of variance to verify if there was effect of the growth condition and the interactions between growth condition 
and the other factors studied. The means of the experiments and cultivars were compared by the Tukey test at $5 \%$ probability. Nitrogen rates were evaluated by regression analysis. The statistical program SISVAR was used.

\section{Results and discussion}

The final population of common bean plants was not affected by cultivars and $\mathrm{N}$ rates, varying only between the experiments (growth conditions). In the "dry" season experiment, 131,000 plants ha ${ }^{-1}$ were obtained, while in the "rainy" season experiment, the average population was 173,000 plants $\mathrm{ha}^{-1}$. This result probably occurred due to the planting and soil moisture conditions in the germination and emergence phases.
The cycle of cultivars was not affected by $\mathrm{N}$ rates. Cultivars BRS Notável and IAC Imperador showed a cycle of 78 days, on average 9 days shorter than the other cultivars (87 days). In the "dry" season experiment, the cycle of common bean cultivars averaged 8 days shorter than in the "rainy" season, which was due to higher temperatures, especially at the beginning of the cycle (Figure 1).

Regarding $\mathrm{N}$ concentration in the diagnostic leaf of common bean plants, there was only effect of the isolated factors (Table 1). Common bean cultivation during the "dry" season, in succession to black oat/millet, provided a higher leaf $\mathrm{N}$ concentration. This result may have occurred mainly due to the higher amount of $\mathrm{N}$ accumulated in the straw and lower $\mathrm{C} / \mathrm{N}$ ratio of the preceding crop, which, together with higher water availability and temperature in early February, provided higher $\mathrm{N}$ uptake by bean plants (Figure 1).

Table 1 - Leaf $\mathrm{N}$ concentration (LNC), grain yield (GY), number of pods per plant (NPP), number of grains per pod (NGP), 100-grain weight (100W), relative grain yield retained in sieves (RYRS), sieve yield (SY), and crude protein concentration in grains (CPC) of common bean cultivars grown during "dry" and "rainy" season in response to topdressing $\mathrm{N}$ rates.

\begin{tabular}{|c|c|c|c|c|c|c|c|c|}
\hline Treatments & $\begin{array}{c}\text { LNC } \\
\left(\mathrm{g} \mathrm{kg}^{-1}\right)\end{array}$ & $\begin{array}{c}\mathrm{GY} \\
\left(\mathrm{kg} \mathrm{ha}^{-1}\right)\end{array}$ & NPP & NGP & $\begin{array}{c}\text { W100 } \\
(\mathrm{g})\end{array}$ & RYRS & $\begin{array}{l}\text { SY } \\
(\%)\end{array}$ & $\begin{array}{c}\mathrm{CPC} \\
\left(\mathrm{g} \mathrm{kg}^{-1}\right)\end{array}$ \\
\hline \multicolumn{9}{|l|}{ Experiment $(\mathrm{E})$} \\
\hline Dry season & $44.6 \mathrm{a}$ & $3,333 b$ & $21.5 a$ & $5.1 \mathrm{a}$ & $27.4 a$ & $7.8 b$ & $86.5 b$ & $265 a$ \\
\hline Rainy season & $40.7 b$ & $3,776 a$ & $20.0 \mathrm{~b}$ & $4.8 b$ & $27.4 a$ & $8.4 a$ & $92.1 \mathrm{a}$ & $239 b$ \\
\hline \multicolumn{9}{|l|}{ Cultivar (C) } \\
\hline Pérola & $44.1 \mathrm{ab}$ & $3,385 b$ & $18.3 b$ & $4.7 c d$ & $28.3 b$ & $8.2 a b$ & $89.5 a$ & $245 b$ \\
\hline BRS Ametista & $42.5 a b c$ & $3,533 b$ & $18.2 \mathrm{~b}$ & $4.9 \mathrm{bcd}$ & $30.5 a$ & $8.0 \mathrm{bc}$ & $89.7 a$ & $262 a$ \\
\hline BRS Notável & $41.0 \mathrm{bc}$ & $3,575 b$ & $21.9 a$ & $4.8 \mathrm{bcd}$ & $25.6 d$ & 8.4ab & $91.0 \mathrm{a}$ & $256 a b$ \\
\hline IPR Campos Gerais & $44.6 a$ & $3,573 b$ & $17.7 \mathrm{~b}$ & $5.2 a b$ & $28.0 \mathrm{~b}$ & $8.2 a b$ & $91.1 \mathrm{a}$ & $254 a b$ \\
\hline IPR Tangará & $44.0 \mathrm{ab}$ & $4,054 a$ & $23.0 \mathrm{a}$ & $5.3 a$ & $26.0 \mathrm{~cd}$ & $8.6 a$ & $92.7 \mathrm{a}$ & $244 b$ \\
\hline IAC Formoso & $42.9 a b$ & $3,363 b$ & $23.1 \mathrm{a}$ & $5.0 \mathrm{abc}$ & $26.9 c$ & 7.7c & $85.2 b$ & $255 a b$ \\
\hline IAC Imperador & $39.2 \mathrm{c}$ & $3,397 b$ & $23.0 \mathrm{a}$ & $4.6 \mathrm{~d}$ & $26.4 \mathrm{~cd}$ & $7.6 c$ & $86.2 b$ & $245 b$ \\
\hline \multicolumn{9}{|l|}{ Nitrogen (kg ha-1) } \\
\hline 0 & 42.4 & 3,363 & 19.7 & 4.9 & 27.2 & 7.9 & 87.8 & 256 \\
\hline 35 & 41.3 & 3,466 & 19.6 & 5.0 & 27.2 & 8.1 & 88.9 & 249 \\
\hline 70 & 42.6 & 3,584 & 20.9 & 4.8 & 27.1 & 8.2 & 89.8 & 246 \\
\hline 140 & 44.1 & 3,819 & 22.7 & 5.0 & 28.0 & 8.3 & 90.7 & 256 \\
\hline Regression & $\mathrm{L}^{(1)}$ & $\mathrm{L}^{(2)}$ & $\mathrm{L}^{(3)}$ & ns & $\mathrm{Q}^{(4)}$ & $\mathrm{L}^{(5)}$ & $\mathrm{L}^{(6)}$ & $Q^{(7)}$ \\
\hline$E \times C$ & ns & $<0.001$ & $<0.001$ & ns & $<0.001$ & $<0.001$ & $<0.001$ & 0.018 \\
\hline$E \times N$ & ns & 0.004 & ns & ns & 0.002 & ns & ns & $<0.001$ \\
\hline $\mathrm{C} \times \mathrm{N}$ & ns & ns & ns & ns & $<0.001$ & ns & ns & 0.003 \\
\hline $\mathrm{E} \times \mathrm{C} \times \mathrm{N}$ & ns & ns & ns & ns & ns & ns & ns & ns \\
\hline CV (\%) & 10.8 & 16.6 & 20.9 & 10.7 & 4.7 & 6.9 & 4.9 & 6.4 \\
\hline
\end{tabular}

Means followed by equal letters, in the columns within each factor (experiment/growth condition and cultivar), do not differ by Tukey's test, at $5 \%$ probability. ${ }^{(1)} y=41.66+0.0157^{* *} x R^{2}=0.66 ;{ }^{(2)} y=3349.08+3.3581^{* *} x R^{2}=0.98 ;{ }^{(3)} y=19.34+0.0230^{* *} x$ $R^{2}=0.93 ;{ }^{\left({ }^{4}\right)} y=27.28-0.0082^{\star *} x+0.0001^{\star *} x^{2} R^{2}=0.94 ;{ }^{(5)} y=7.96+0.0025^{\star *} \times R^{2}=0.98 ;{ }^{(6)} y=88.09+0.0204^{\star *} x R^{2}=0.94$; (7) $y=256.43-0,2805^{\star *} x+0.0020^{\star *} x^{2} R^{2}=0.99$. ns Nonsignificant; * and ** Significant by the t-test at 5 and $1 \%$ probability, respectively. 
According to Cantarella (2007), C/N ratio values between 12 and 25 favor $\mathrm{N}$ mineralization of the remaining straw and, consequently, greater availability of $\mathrm{N}$ for the subsequent crop. Cultivar IPR Campos Gerais presented the highest leaf $\mathrm{N}$ concentration, differing from BRS Notável and IAC Imperador, which may have occurred, among other factors, due to the difference in the nutritional requirement of each cultivar (Table 1). Topdressing $\mathrm{N}$ fertilization linearly increased the $\mathrm{N}$ concentration, regardless of the cultivar. Increases in leaf $\mathrm{N}$ concentrations in common bean plants as a function of $\mathrm{N}$ fertilization were reported by Soratto et al. (2004), Soratto et al. (2013a; 2017), Soratto et al. (2014), and Maia et al. (2017). However, in all treatments, leaf $\mathrm{N}$ concentrations were within the range considered suitable for common bean cultivation, which is between 30 and $50 \mathrm{~g} \mathrm{~kg}^{-1}$ (Ambrosano et al., 1997).

Grain yield was influenced by the experiment, cultivar, $\mathrm{N}$ rate, and by the interactions experiment $x$ cultivar and experiment $\times \mathrm{N}$ rate (Table 1 ). In the "dry" season, common bean cultivars showed no difference in grain yield (Table 2). In the "rainy" season, the highest grain yield was obtained with cv. IPR Tangará $\left(4,498 \mathrm{~kg} \mathrm{ha}^{-1}\right)$, which differed from cultivars IAC Formoso, Pérola, BRS Notável, and IAC Imperador. The highest grain yield obtained in cV. IPR Tangará was mainly due to the combination of the relatively high number of pods per plant and number of grains per pod (Tables 1 and 2). In the absence of topdressing $\mathrm{N}$ fertilization, the grain yield of common bean cultivars obtained in the "dry" and "rainy" season experiments did not differ statistically (Table 3 ). However, when topdressing $\mathrm{N}$ fertilization was applied, the highest grain yields were obtained in the "rainy" season experiment. In fact, this experiment was the only one in which grain yield was affected by $\mathrm{N}$ application, with linear adjustment, regardless of the cultivar. The higher response to $\mathrm{N}$ in the "rainy" season experiment is probably related to the lower amount of $\mathrm{N}$ and higher $\mathrm{C} / \mathrm{N}$ ratio in the maize straw preceding common bean cultivation.

Table 2 - Experiment (growth condition) $\times$ cultivar interaction for grain yield, number of pods per plant, 100-grain weight, relative grain yield retained in sieves, sieve yield, and crude protein concentration in grains of common bean crop. Average of four topderssing $\mathrm{N}$ rates.

\section{Cultivar}

$\begin{array}{lccccccc}\text { Exp. } & \text { Pérola } & \text { BRS Amestist } & \text { BRS Notável } & \text { IPR Campos } \\ \text { Gerais } & \text { IPR Tangará } & \text { IAC Formoso } & \text { IAC } \\ \text { Imperador }\end{array}$

Means followed by equal lowercase letters in the columns (experiment/growth condition) and uppercase letters in the rows (cultivars) do not differ by Tukey's test, at $5 \%$ probability.

The 100-grain weight was affected by the isolated factors and by the interactions experiment $\times$ cultivar, experiment $\times \mathrm{N}$ rate, and cultivar $\times \mathrm{N}$ rate (Table 1). However, in general, cv. BRS Ametista presented higher grain weight than the other cultivars, and there was no consistent effect of the experiment or
$\mathrm{N}$ application on the grain weight of the cultivars (Tables 2 and 4). Considering the average of the cultivars, $\mathrm{N}$ application increased grain weight only in the "dry" season experiment (Table 3). The results indicate that the response to topdressing $\mathrm{N}$ fertilization was more related to environmental conditions than to 
the cultivar used, as reported by Soratto et al. (2004), Soratto et al. (2014), and Soratto et al. (2017). Differences in topdressing $\mathrm{N}$ rates to be applied in common bean crop may be related to growing seasons, remaining straw, grain yield (Ambrosano et al., 1997), soil management system (Soratto et al. 2004; Soratto et al., 2014), climatic conditions, N sources, $\mathrm{N}$ availability in the soil solution, and $\mathrm{N}$ dynamics in the soil-plant system (Soratto et al., 2004; Cantarella 2007).

Table 3 - Experiment (growth condition) $\times$ topdressing $\mathrm{N}$ rate interaction for grain yield, 100-grain weight, and crude protein concentration in grains of common bean crop. Average of seven cultivars.

\begin{tabular}{|c|c|c|c|c|c|c|}
\hline \multirow{2}{*}{ Experiment } & \multicolumn{4}{|c|}{ Nitrogen $\left(\mathrm{kg} \mathrm{ha}^{-1}\right)$} & \multirow{2}{*}{ Regression } & \multirow{2}{*}{$\mathrm{R}^{2}$} \\
\hline & 0 & 35 & 70 & 140 & & \\
\hline \multicolumn{7}{|c|}{ Grain yield $\left(\mathrm{kg} \mathrm{ha}^{-1}\right)$} \\
\hline Dry & $3,330 \mathrm{a}$ & $3,235 b$ & $3,365 b$ & $3,401 b$ & ns & - \\
\hline Rainy & $3,396 a$ & $3,711 a$ & $3,725 a$ & $4,272 \mathrm{a}$ & $y=3412.89+5.9362^{* *} x$ & 0.95 \\
\hline \multicolumn{7}{|c|}{ 100-grain weight $(\mathrm{g})$} \\
\hline Dry & $26.9 b$ & $27.0 \mathrm{a}$ & $27.4 a$ & $28.3 a$ & $y=26.71+0.0110^{* *} x$ & 0.96 \\
\hline Rainy & $27.6 a$ & $27.6 \mathrm{a}$ & $26.7 \mathrm{~b}$ & $27.7 a$ & ns & - \\
\hline \multicolumn{7}{|c|}{ Crude protein concentration in grains $\left(\mathrm{g} \mathrm{kg}^{-1}\right)$} \\
\hline Dry & $264 a$ & $263 a$ & $270 a$ & $263 a$ & ns & - \\
\hline Rainy & $248 b$ & $234 b$ & $223 b$ & $250 b$ & $y=249.66-0,6947^{* *} x+0.0050^{* *} x^{2}$ & 0.97 \\
\hline
\end{tabular}

Means followed by equal letters in the columns (experiment/growth condition) do not differ by Tukey's test, at 5\% probability. ns Nonsignificant. * and ${ }^{* *}$ Significant by the t-test, at 5 and $1 \%$ probability, respectively.

Relative sieved grain yield (RSGY) and sieve yield (SY) were influenced by experiment, cultivar, $\mathrm{N}$ rate, and by the interaction experiment $\times$ cultivar (Table 1). Cultivar IAC Formoso presented higher RSGY and SY values in the "dry" season experiment, in contrast to the other cultivars (Table 2). In general, in the "dry" season, the highest values of RSGY (8.3) and SY $(89 \%)$ were obtained in Cv. IPR Tangará, which differed statistically from cv. IAC Imperador. In the "rainy" season experiment, the highest values of RSGY were obtained in cultivars IPR Campos Gerais and IPR Tangará (8.9), which differed statistically from cultivars IAC Formoso and IAC Imperador. Still in this growing season, the highest SY value was observed in cV. IPR Tangará $(96.4 \%)$, which differed statistically from cultivars IAC Formoso and IAC Imperador. Similar results were obtained in a study conducted by Carbonell et al. (2010), which evaluated SRGY and SY in 19 common bean genotypes grown during the "dry", "rainy", and "winter" seasons. The authors also observed differences between genotypes and growing seasons for both variables. According to these authors, the bean market has a greater demand for grains classified in sieves 13 and 14; therefore, these grains are more valued by the packaging industry. Regardless of cultivar and experiment, $\mathrm{N}$ application linearly increased RSGY and SY values (Table 1). These results corroborate those obtained by Soratto et al. (2011), who verified that $\mathrm{N}$ fertilization provided higher quality grains for CV. IAC Alvorada, indicated by the higher values of
RSGY, in the absence of foliar $\mathrm{N}$ application or when it was only performed in the $\mathrm{R}_{5}$ stage.

The crude protein concentration in the grains was influenced by the isolated factors and by the interactions experiment $\times$ cultivar, experiment $\times \mathrm{N}$ rate, and cultivar $\times \mathrm{N}$ rate (Table 1). All cultivars showed the highest grain protein concentration in the "dry" season experiment (Table 2), which was probably due to the higher amount of $\mathrm{N}$ accumulated in the straw and lower $\mathrm{C} / \mathrm{N}$ ratio of the preceding crop. This may have provided greater $\mathrm{N}$ uptake by the common bean, as evidenced by the higher $\mathrm{N}$ concentration in the diagnostic leaf and by the absence of effect of $\mathrm{N}$ rates on the grain protein concentration of bean plants grown in the "dry" season (Tables 1 and 3). In the "dry" season experiment, there was a difference between cultivars regarding crude protein concentration in the grains. The highest values were observed in cultivar 'RS Amestita, which differed from IPR Tangará and IAC Imperador (Table 2). In the "rainy" season experiment, the highest protein concentrations were obtained in cultivars BRS Ametista and BRS Notável. The "rainy" season accounted for lower concentrations of crude protein in the grains with the application of intermediate $\mathrm{N}$ rates (35 and $70 \mathrm{~kg} \mathrm{ha}^{-1}$ ), probably due to the significant increase in grain yield, which was not accompanied by proportional increases in $\mathrm{N}$ uptake, causing a dilution effect. According to Soratto et al. (2013b), most of the $\mathrm{N}$ taken up by common bean $(58-69 \%)$ is remobilized to the grains at the beginning of the reproductive phase, being especially a component of proteins 
(Malavolta et al., 1997). The interaction cultivar $\times \mathrm{N}$ rate showed a great variation between the cultivars within the different $\mathrm{N}$ rates, and inconsistent effects of $\mathrm{N}$ rates on the crude protein concentration of bean grains (Table 4). In general, the protein concentration ranged from 232 to $271 \mathrm{~g} \mathrm{~kg}^{-1}$, and intermediate $\mathrm{N}$ rates provided lower values. These increases may be related to some increase in the crude protein concentration in the grains (Table 4), but mainly to the higher grain yields provided by $\mathrm{N}$ fertilization (Tables 1 and 3 ).

Table 4 - Cultivar $\times$ topdressing $N$ rate interaction for 100-grain weight and crude protein concentration in grains of common bean crop. Average of two experiments (growth conditions).

\begin{tabular}{|c|c|c|c|c|c|c|}
\hline \multirow{2}{*}{ Cultivar } & \multicolumn{4}{|c|}{ Nitrogen $\left(\mathrm{kg} \mathrm{ha}^{-1}\right)$} & \multirow{2}{*}{ Regressão } & \multirow{2}{*}{$\mathrm{R}^{2}$} \\
\hline & 0 & 35 & 70 & 140 & & \\
\hline & \multicolumn{4}{|c|}{ 100-grain weight $(\mathrm{g})$} & & \\
\hline Pérola & $29.3 a$ & $27.2 \mathrm{bc}$ & $28.0 \mathrm{~b}$ & $28.8 a b$ & ns & - \\
\hline BRS Ametista & $29.2 a$ & $31.5 a$ & $30.7 a$ & $30.7 a$ & ns & - \\
\hline BRS Notável & $25.7 b$ & $25.7 \mathrm{~cd}$ & $24.9 d$ & $26.3 c$ & ns & - \\
\hline IPR Campos Gerais & $27.5 a b$ & $28.7 b$ & $27.9 b$ & $27.8 \mathrm{bc}$ & ns & - \\
\hline IPR Tangará & $26.0 \mathrm{~b}$ & $25.0 d$ & $25.1 \mathrm{~cd}$ & $27.8 \mathrm{bc}$ & $y=25.98-0.0396^{\star *} x+0.0004^{\star *} x^{2}$ & 0.99 \\
\hline IAC Formoso & $26.7 b$ & $27.5 b c$ & $26.1 \mathrm{bcd}$ & $27.4 \mathrm{bc}$ & ns & - \\
\hline \multirow[t]{2}{*}{ IAC Imperador } & $26.2 b$ & $25.2 d$ & $26.8 \mathrm{~cd}$ & $27.3 b c$ & ns & - \\
\hline & \multicolumn{4}{|c|}{ Crude protein concentration in grains ( $\mathrm{g} \mathrm{kg}$} & & \\
\hline Pérola & $252 a b$ & $241 a$ & $234 a b$ & $253 a b$ & $y=253.29-0.498^{* *} x+0.0036^{* *} x^{2}$ & 0.98 \\
\hline BRS Ametista & $268 a$ & $255 a$ & $256 a b$ & $271 \mathrm{a}$ & $y=267.36-0.3928^{*} x+0.0030^{*} x^{2}$ & 0.95 \\
\hline BRS Notável & $271 \mathrm{a}$ & $250 a$ & $244 a b$ & $260 \mathrm{ab}$ & $y=270.97-0.717^{\star \star} x+0.0046^{\star \star} x^{2}$ & 0.99 \\
\hline IPR Campos Gerais & $263 a b$ & $255 a$ & $244 a b$ & $255 a b$ & $y=264.70-0.4498^{*} x+0.0027^{*} x^{2}$ & 0.90 \\
\hline IPR Tangará & $254 a b$ & $245 a$ & $232 b$ & $246 b$ & $y=255.72-0.5123^{*} x+0.0032^{*} x^{2}$ & 0.90 \\
\hline IAC Formoso & $242 b$ & $258 a$ & $256 a b$ & $266 a b$ & $y=246.43+0.1531^{* *} x$ & 0.79 \\
\hline IAC Imperador & $242 b$ & $237 a$ & $258 a$ & $243 b$ & ns & - \\
\hline
\end{tabular}

Means followed by equal letters in the columns (cultivar) do not differ by Tukey's test, at $5 \%$ probability. ${ }^{\text {ns Nonsignificant. }{ }^{*} \text { and }}$ ${ }^{*}$ Significant by the $t$-test, at 5 and $1 \%$ probability, respectively.

\section{Conclusions}

Topdressing $\mathrm{N}$ application did not affect the cycle, plant population, and number of grains per pod, but increased the leaf $\mathrm{N}$ concentration, number of pods per plant, grain yield, relative sieved grain yield, and sieve yield of common bean plants, regardless of the cultivar.

The responses of common bean cultivars to topdressing $\mathrm{N}$ rates varied according to the growth condition. Nitrogen response was only observed in the "rainy" season experiment, under conditions of lower $\mathrm{N}$ and higher $\mathrm{C} / \mathrm{N}$ ratio in the straw of the preceding crop.

The crude protein concentration in the grains was influenced in an inconsistent manner by the factors studied.

\section{Acknowledgements}

To CNPq for granting scholarships to the first and second authors. To EMBRAPA, IAC, and IAPAR for the supply of seeds.

\section{References}

Amaral CB, Pinto CC, Flôres JA, Mingotte FLC, Lemos LB, Fornasieri Filho D (2016) Produtividade e qualidade do feijoeiro cultivado sobre palhadas de gramíneas e adubado com nitrogênio em plantio direto. Pesquisa Agropecuária Brasileira 51(9):1602-1609.

Ambrosano EJ, Tanaka RT, Mascarenhas HAA, Raij B van, Quaggio JA, Cantarella H (1997) Leguminosas e oleaginosas. In: Raij B van, Cantarella H, Quaggio JA, Furlani AMC (eds.) Recomendação de adubação e calagem para o Estado de São Paulo. Campinas, IAC. p.189-203.

Cantarella H (2007) Nitrogênio. In: Novais FR, Alvarez VVH, Barros NF, Fontes RLF, Cantarutti RB, Neves JCL (eds.) Fertilidade do solo. Viçosa, SBCS. p.375-470 .

Carbonell SAM, Chiorato AF, Gonçalves JGR, Perina EF, Carvalho CRL (2010) Tamanho de grão comercial em cultivares de feijoeiro. Ciência Rural 40(10):2067$-2073$. 
Chagas JM, Braga JM, Vieira C, Salgado LT, Junqueira Neto A, Araújo GAA, Andrade MJB, Lana RMQ, Ribeiro AC (1999) Feijão. In: Ribeiro AC, Guimarães PTG, Venegas, VHA (eds.) Recomendações para o uso de corretivos e fertilizantes em Minas Gerais - 5ạ Aproximação. Viçosa, UFV. p.306-307.

CONAB - Companhia Nacional de Abastecimento (2018) Levantamentos de Safra. Disponível em: <http://www.conab.gov.br/conteudos.php?a=1253\&t>. Acesso em 26 de jan. de 2018.

Fornasieri Filho D, Xavier MA, Lemos LB, Farinelli $R$ (2007) Resposta de cultivares de feijoeiro comum à adubação nitrogenada em sistema de plantio direto. Científica 35(2):115-121.

Guimarães RAM, Braz AJBP, Simon GA, Ferreira CJB, Braz GBP, Silveira PM (2017) Resposta de cultivares de feijoeiro à adubação nitrogenada em diferentes estádios fenológicos. Global Science and Technology 10(1):136-148.

Lemos LB, Mingotte FLC, Farinelli R (2015) Cultivares. In: Arf O, Lemos LB, Soratto RP, Ferrari S (eds.) Aspectos gerais da cultura do feijão (Phaseolus vulgaris L.). Botucatu, FEPAF. p.181-207.

Maia SCM, Soratto RP, Liebe SM, Almeida AQ (2017) Criteria for topdressing nitrogen application to common bean using chlorophyll metter. Pesquisa Agropecuária Brasileira 52(7):512-520.

Malavolta E, Vitti GC, Oliveira AS (1997) Avaliação do estado nutricional de plantas: princípios e aplicações. Piracicaba, POTAFOS. 308p.

Salgado FHM, Silva J, Oliveira TC, Barros HB, Passos N.G, Fidelis RR (2012) Eficiência de genótipos de feijoeiro em resposta à adubação nitrogenada. Pesquisa Agropecuária Tropical 42(4):368-374.

Santos AB, Fageria NK (2007) Manejo do nitrogênio para eficiência de uso por cultivares de feijoeiro em várzea tropical. Pesquisa Agropecuária Brasileira 42(9):1237-1248.
Santos HG, Jacomine PKT, Anjos LHC, Oliveira VA, Lubreras JF, Coelho MR, Almeida JA, Cunha TJF, Oliveira JB (2013). Sistema brasileiro de classificação de solos. Brasília, EMBRAPA. 353p.

Soratto RP, Carvalho MAC, Arf O (2004) Teor de clorofila e produtividade do feijoeiro em razão da adubação nitrogenada. Pesquisa Agropecuária Brasileira 39(9):895-901.

Soratto RP, Catuchi TA, Souza ECS, Garcia JLN (2017) Plant density and nitrogen fertilization on common bean nutrition and yield. Revista Caatinga 30(3):670-678.

Soratto RP, Fernandes AM, Pilon C, Crusciol CAC, Borghi E (2013를 Épocas de aplicação de nitrogênio em feijoeiro cultivado após milho solteiro ou consorciado com braquiária. Pesquisa Agropecuária Brasileira 48(10):1351-1359.

Soratto RP, Fernandes AM, Santos LA, Job ALG (2013b) Nutrient extraction and exportation by common bean cultivars under different fertilization levels: I - Macronutrients. Revista Brasileira de Ciência do Solo 37(4):1027-1042.

Soratto RP, Fernandes AM, Souza ECS, SouzaSchlick GD (2011) Produtividade e qualidade dos grãos de feijão em função da aplicação de nitrogênio em cobertura e via foliar. Revista Brasileira de Ciência do Solo 35(6):2019-2028.

Soratto RP, Perez AAG, Fernandes AM (2014) Age of no-till system and nitrogen management on common bean nutrition and yield. Agronomy Journal 106(3):809820.

Sousa DMG, Lobato E (2004) Calagem e adubação para culturas anuais e semiperenes. In: Sousa DMG, Lobato E (eds.) Cerrado: correção do solo e adubação. Brasília, Embrapa Informação Tecnológica. p.283-316. 